\title{
5. Contested Spaces
}

The Oranienplatz Protests, Berlin, 2012-2014

\begin{abstract}
"In the morning, when asylum seekers wake up, they are scared of being deported. If they want to meet friends, the Residenzpflicht ${ }^{1}$ prevents them from doing so. Everywhere in their life, hurdles exist, built by the state, because we are not meant to be part of society."
\end{abstract}

\begin{abstract}
In early 2012, the suicide of an Iranian asylum seeker in Würzburg initiated the most disruptive precarious migrant protests in German history. Starting as a spark of protest against the living conditions in one specific asylum facility in southern Germany, the dissent soon spread. Tent camps emerged in other cities and in September 2012, the scattered camps joined forces and organized a bus tour as well as a $600 \mathrm{~km}$ protest march to Berlin. This chapter analyzes how precarious migrants were able to raise public attention and mobilize asylum seekers and the media by moving from socially and spatially isolated locations into urban centers. In organizing central protest camps, marches and bus tours, they broke the routine of precarious migrant invisibility or victimization. In and through contested spaces, they temporarily succeeded in tapping the resources needed to sustain political mobilizations.
\end{abstract}

Keywords: migrant protest; space; protest camps; interactions; alliances; Berlin

Despite countless protest events, and more or less sustained organizational structures since the 1990s, precarious migrant protest remained at the margins of German society. National newspapers rarely reported on the activities and

1 Mobility restriction in German foreigners' law. See Chapter 2 for details.

2 Cited in Jakob (2013), author's translation.

Steinhilper, E., Migrant Protest: Interactive Dynamics in Precarious Mobilizations. Amsterdam: Amsterdam University Press 2021 DOI: 10.5117/9789463722223_CHO5 
solidarity was limited to the radical left and some faith-based associations. This changed fundamentally in early 2012, when the suicide of an Iranian asylum seeker in Würzburg initiated the most disruptive precarious migrant protests in German history. In reaction to their friend's death, fellow Iranians started to politicize the suicide, boycotted their food packages, and demonstrated in front of the city hall, demanding the improvement of living conditions during the asylum process, accelerated procedures, and an end to all deportations. To increase the pressure, the protesters left their assigned accommodation, set up very basic tents in the city center, displayed photographs of human rights abuses in Iran and declared they were going on hunger strike. Starting as a spark of protest against the living conditions in one specific asylum facility in southern Germany, the dissent soon spread. Tent camps ${ }^{3}$ emerged in other cities, loosely knit together in the "Refugee Tent Action" campaign (International Refugee Center Berlin 2015). In September 2012, the scattered camps joined forces and organized a bus tour as well as a $600 \mathrm{~km}$ protest march to Berlin. In the upcoming months, until its dissolution in April 2014, the camp constituted the center of self-organized precarious migrant protest in Germany.

The trajectory of the protests furthermore clearly shows that the protesters did not react upon opening opportunity structures, as the traditional social movement theories would expect. Instead, their protest, emerging in the most restrictive regional context for asylum seekers in Bavaria, actively opened up opportunities. Yet, the account also illustrates the dynamics of fragmentation related to internal heterogeneity, volatile external support and precarious life conditions, which make protest hard to sustain.

\section{Resisting Spatial Exclusion: Protest Emergence in Würzburg}

On 29January 2012, the young Iranian Mohammad Rahsepar committed suicide in his room in a facility for asylum seekers in Würzburg, in the German state of Bavaria. According to fellow asylum seekers and Rahsepar's doctor, the miserable accommodation, lack of adequate medical assistance, and the insecurity and waiting in an isolated facility had gradually pushed him into depression (Jungbauer 2012). In reaction to their friend's death, fellow Iranians accommodated in the same facility started to politicize the suicide, associating it with the precarious conditions, structural disintegration, lack

3 The camps differ markedly from the makeshift camps described in Chapter 4, since they were primarily set up for disruptive purposes and not to provide precarious shelter as in the case of the La Chapelle protests. 
of autonomy and limited mobility in the German asylum system. Indeed, an investigation following the suicide of Rahsepar in 2012 concluded that "the fact that someone commits suicide does not say anything. However, it is a system, exercising structural violence" (cited in Jakob 2016: 108, author's translation). The respective collective accommodation center in Würzburg was, like many others at the time (Wendel 2014), a repurposed army barracks, located in an industrial area at the outskirts of the city, surrounded by highways and production sites, separated from ordinary social life.

While the spark of protest emerged within this restrictive and isolated environment, its continuation was strongly shaped by a relocation of the protest from the urban periphery to the city center. After a first protest outside the asylum facility, the protesters left their assigned accommodation, set up a very basic tent in the city center and displayed photographs of human rights abuses in Iran, to underline the legitimacy of their presence in Germany and the indignity of their treatment. Soon, the protesters were surrounded by a heterogeneous mix of actors declaring their support, ranging from members of the regional and national parliament from the Greens and the Left, anarchist and communist groups, the Iranian diaspora in Germany and local antiracist and faith-based associations (Grünberg 2013; Jungbauer 2012). The involvement of a radical supporting milieu from the outset, in addition to the local migrant rights scene, was not coincidental, given the biographies of several members of the core group of Iranians. Many had been engaged as students in the Iranian "Green Movement" against authoritarian Iranian president Mahmoud Ahmadinejad in 2009 and were prosecuted subsequently. Due to this background, they had some links to the Iranian exile community, and as Marxist students, an affinity to radical left-wing groups (Interviews B11, B22, B26). After a couple of weeks, the protesters increased the pressure and declared they were going on hunger strike:

We suffer from the extremely long asylum process that sometimes takes even years and we hope every day that the torture of uncertainty will change for the better. [...] This uncertainty, the fact that no autonomy is allowed to us in our daily lives, and that we are treated like prisoners, exhausts us and gradually - step by step - pushes us toward death. [...] Now, we are forced to use the last of all means available and go on hunger strike on 19 March 2012, to finally make our voices heard, and to be allowed a human life. (Hosinazadeh and Maorattab 2012, author's translation)

Due to its central location and the radical tactic of a hunger strike, the unfolding protest arena immediately attracted the attention of the local 
population, the media and asylum seekers from other cities in the region (Litschko 2012b; Przybilla 2012b; Jungbauer 2012). Set up in one of the central streets in Würzburg, the very presence of the asylum seekers in the public space constituted a rupture of the exclusive routine, leading to both open opposition of the protest and expressions of solidarity (Grünberg 2013).

The Bavarian minister of social affairs, Christine Haderthauer (CSU4), refused to meet the protesters - arguing that the state would not be "blackmailed" (Main Post 2012a) - yet the deputy director of the German asylum agency, in charge of refugee status determination (BMBF5), came for a meeting. The public exposure attracted visibility and resources for the continuation of the protest. Increasingly aware of this incubating effect, the municipality of Würzburg employed various tactics to get rid of the camp by imposing bizarre rules: First, the administration limited the amounts of chairs and beds allowed in the camp (Jakob 2016: 109). The administrative court annulled this prohibition shortly after. Furthermore, the municipality increased the control of those individuals who joined the camp in Würzburg but were officially registered in other districts and thereby subject to Residenzpflicht (restrictions on mobility) (Refugee Tent Action 2012).

The socialization of the core group of Iranian protesters in an authoritarian regime soon became both the force of their determination and an irritation to some of those acting in support. At the outset, many actors, including local politicians, supported both the forms of action and the demands of the protesters. Yet, this changed in early summer 2012, when the protesters further escalated the conflict. In an open letter, they reiterated their demands, which they concluded with the line "There is nothing more to say; everything has been said" (cited in Grünberg 2013: 166). After that, two protesters sewed their lips to underline their voicelessness and determination. Five other Iranian asylum seekers followed their example during the upcoming week. This choice of strategy had an ambivalent effect. On the one hand, the images of sewed mouths were diffused heavily in the German media, and the visibility of the protests expanded even further on a national scale (Augsburger Allgemeine 2012; Die Welt 2012; Przybilla 2012a, 2012c). On the other hand, the self-destructive means alienated parts of the players acting in support. The vice-director of the largest asylum-related NGO in Germany, Pro Asyl, criticized the timing of the escalation of protest 
and noted that his organization had "immense problems with any kind of protest, which is directed against one's health" (cited in Die Welt 2012, author's translation). Also the Refugee Council of Bavaria, which was usually strongly supportive of the group, criticized these actions (Przybilla 2012c). Mathias Grünberg, a local politician for the Greens who had supported the protests for weeks, remarked in an open letter:

The sewing of your mouth is unacceptable! From this moment, I cannot come any longer to your info point. I - and it is not only me - cannot do anything politically. The implementation of your just demands will take months, indeed years. I do not consider this action [lip sewing] to be appropriate to advance your - our - demands. No, it only damages your health, indeed, your life. (Grünberg 2013: 102, author's translation)

Simone Tolle, a member of the regional parliament for the Green Party, also distanced herself. She noted that the protest repertoire had not only alienated her but "a lot of persons have contacted me [to say that] they have problems with this kind of protest" (Grünberg 2013: 106, author's translation). Indeed, the leading local newspaper commented:

You do not make friends like this, no matter how good and just the cause is for which the Iranian refugees are protesting. This "new rigidity" [a quote from the protesters] will backfire on them. Until now, they have built their protest on the sympathies in sections of society, [...] but by doing things like this, needy refugees quickly become incalculable radicals. (Main Post 2012b, author's translation)

One of the supporters responded sarcastically in a published letter to the editor:

What kind of protest do you expect? Knitting socks for the winter? A concert by an Iranian strikers' choir, combined with collecting money for asylum seekers? Once more a day of sympathy from the population, which ends the next day when a demonstration disrupts the routine of Saturday shopping? No, here, human beings fight for their rights. It is not about who likes whom and who does not. It is not about friends and sympathy. It is about humanity. (Neuert 2012, author's translation)

This change in the repertoire marked a critical shift as it restructured the supporting milieu. The more institutionalized actors (most party 
representatives, NGOs) became somehow alienated after a strong initial support, whereas decentralized antiracist groups stepped in:

We declare our unconditional solidarity with the demands of the refugees. With consternation, however, we have realized that some groups and individuals defame their protest. [...] The questions is: Are those expressing criticism overwhelmed by this freely chosen form of protest or do they feel threatened in their role as paternalistic pro-beneficiaries? (Cited in Grünberg 2013: 165, author's translation)

What started as a debate about "adequate" repertoires of action eventually broadened into a general debate about the legitimacy of nonmigrants to evaluate protest by precarious migrants:

The radicalized hunger strike of the Iranian refugees with sewed lips is, without doubt, a last, desperate attempt to make self-determined claims and to prove their ability to act. No one, particularly no one living in Germany, who enjoys all political and liberal rights, can presume to be in a position to judge which means refugees are allowed to take. (Möller 2012, author's translation)

The protesting migrants, in turn, disqualified criticism as "desolidarization" (Refugee Tent Action 2012). By the end of June, one of the protesters pushed even further and stopped drinking water. The protesters ended their hunger strike and removed the threads in their lips when the majority of protesters were granted refugee status (Przybilla 2012b, 2012c). Due to their determination, the Iranians quickly earned a reputation for being extremely resolute and less inclined to engage in lengthy debates with supporting environments (Interviews B11, B15, B22, B34). This led to a tension-prone interaction with the established players of the precarious migrant self-organization such as The Voice and the Caravan network. Even though the Caravan had supported the tent actions, by offering the use of their bank account to receive donations and by visiting the camp in Würzburg repeatedly (Grünberg 2013: 246), conflicts over representation and strategy emerged early on (Interviews B11, B25, B34). Moreover, the old generation was not given credit for their share in the new generations' success - the knitting of networks, mobilization in camps and the gradual establishment of a refugee subjectivity within the German left.

The dynamics of 2012 was not something that just fell from heaven. The solidarity, the power of 2012, had been built up over 20 years. When I first 
came to Germany, the relationship between the antiracist movement and the self-organized groups was different. They ignored you. If the old activists [...] had not started to push the idea that refugees should be actors, very particular actors in their own struggle, the protest march would have been crushed. Otherwise, you would have seen refugees standing behind white activists in the front line. (Interview B22)

Thirdly, the sensitive relationship was furthermore rooted in partly antagonistic supporting milieus and ideologies: among the early supporters of the Iranian core group were also adherents of the so-called "anti-German" faction in the German radical left (Interview B34), whose members deduce a strongly pro-Israel and pro-US (as the main guarantor of the state of Israel) position from the German fascist past and a fear of rising German nationalism since the early 1990s (Ullrich 2013). As opponents to the strongly anti-Semitic former president of Iran, Mahmoud Ahmadinejad, the Iranians who were involved in the Green Movement in 2009 were considered natural allies. Yet, other support milieus, and particularly the Caravan, are rooted in an anti-imperialist and pro-Palestinian tradition. Conflicts accentuated when in late August, the new generation of protesters, still predominantly led by the Iranian core group from Würzburg, was invited to the "Break Isolation Summer Camp" in Erfurt, organized by the Caravan and the Voice:

In October 2011, when we started organizing the summer camp for August 2012, we thought it would be the first and only refugee camp in Germany that year. But when the Iranian refugees started their protest tent in March, and the hunger strike of refugees spread to other cities and towns, we realized that many camps were on the way to the refugee summer camp in Erfurt. (The Voice 2012, author's translation)

Questions over representation, leadership, and the role of the former asylum seekers, who had gained a regularized status in the meanwhile, were fought out rigorously from the beginning. Nevertheless, in a moment of collective euphoria about the very fact that precarious migrant protest had come into the limelight, cooperation continued. But "the bruises from Erfurt" were remembered and resurfaced later (Interview B25). ${ }^{6}$ 


\section{Centralizing Dissent: The Protest March to Berlin}

When the protest had spread in the loosely connected "tent action campaign," but temporarily appeared to stagnate, the core group employed another spatial strategy to revitalize the emerging movement: a march and a bus tour to Berlin. Relocating their dissent from the geographical and social margins of society to the German capital was explicitly meant as a claim to centrality: "We are going to the center where everything is close - the authorities, the parliament. We are going to bring the action there. If it was in other places, they can say, 'This is Bavaria, this is local,' so we have to bring it to the center" (Interview B4). Despite the disputes in Würzburg and Erfurt, the Caravan and many other groups supported the march to Berlin logistically since the Iranians could point at their strategy of escalation being successful. At least in the short run, they had politicized the topic of asylum in Germany in an unprecedented way.

The decentralized activist nodes of the Caravan organized accommodation and food on the stops of both the march and the bus tour, building upon local promigrant grassroots infrastructures, including associations as diverse as radical left social centers, sports clubs and faith-based youth organizations (Loschert 2012; Interviews B15, B34). As one participant of the bus tour recalled: "We went to the Caravan, to the Voice [and said], you have been here for a long time: we need connections. First of all, we need a place to meet people. We connected to antifa[scist] and antiracist [organizations] because they are everywhere. They also are in contact with the refugees. They know where the refugees are - we don't" (Interview B4).

Similarly, while criticizing the timing of the escalation by the Würzburg group, Pro Asyl and the refugee councils (Landesflüchtlingsräte) of Bavaria and Berlin raised money and public awareness for the march (Landesflüchtlingsräte and Pro Asyl 2012; Pro Asyl 2012; Pro Asyl and Flüchtlingsrat Berlin 2012). "The regional refugee councils and Pro Asyl align with the demands of the refugees and call for support of the protest march. The refugees urgently depend on donations for food, logistics, and publicity materials" (Landesflüchtlingsräte and Pro Asyl, 2012, author's translation). Without this support, the march and the bus tour to Berlin could not have been organized in such a short time.

The march and the bus tours turned out to have an important relational effect in connecting a geographically dispersed population of asylum seekers in the German periphery. The mobile protest to Berlin was planned to pass deliberately by numerous asylum facilities in order to "pick up noncitizens wherever they are. In every camp, in every room. The movement needs 
to stay in motion" (Houmer Hedayatzadeh, cited in Jakob 2013, author's translation). Every stop during the month-long march added nodes to a growing protest network.

The mobile repertoire, moreover, had an expressive element, since activists intended, symbolically and practically, to appropriate and enact rights. Moving forward, in a literal sense, disrupted the feeling of "being stuck," forcefully immobilized by a lengthy and burdensome administrative procedure. One of the protagonists hence noted: "We did not ask for rights; we did [practiced] our rights" (Interview B4). Underlining their determination to resist forced immobility during the asylum procedure in Germany, the activists tore up their identity documents for asylum seekers (Aufenthaltsgestattung) on the march from Würzburg to Berlin at the former inner German border (Guyton 2012), symbolically relating to a continuity of borders within Germany for those considered unwanted. The internal effect of this "eventful" (della Porta 2008) protest was a deepening of strong emotional ties among those participating.

After four weeks and 600 kilometers of marching, the protesters reached Berlin. By this action, they relocated the spatial center of the protest arena around precarious migration to the German capital. This shift resulted in a continuity of some players, the fade-out of the local involvement by the groups and institutionalized politics in Würzburg and, most importantly, the addition of multiple new players in a much more complex, multilayered and heavily mediatized environment in Berlin.

\section{OPlatz as a Space of Protest Incubation}

Upon arrival in Berlin, the marchers set up a protest camp at Oranienplatz (also referred to as OPlatz), a square in Kreuzberg, which soon became a complex protest arena, in which multiple individual and compound players interacted. Thousands of supporters from a wide range of backgrounds - radical left groups, migrant associations, neighbors, faith-based groups either welcomed the marchers on their arrival or offered their support over the following days. Media coverage was mainly supportive (Guyton 2012; Lindner 2012; Markus 2012) and even the primetime edition of Tagesschau, Germany's most important public television news outlet, reported on the protest (ARD Tagesschau 2012). Kreuzberg's district mayor from the Green Party, Franz Schulz, who had been informed about the camp beforehand, publicly articulated his support for the protest (Rogalla 2012). Even though a small "tent action" protest camp had existed before in the neighborhood, the 
arrival of the march sparked an atmosphere of collective euphoria: "During the [tent action camp] at Heinrichplatz, we, from [the tenant initiative] Kotti \& Co, were in close contact, we also did some night shifts, if support was needed. But when the march arrived in Berlin, at the beginning there were five supporters for every refugee" (Interview B8).

Even more than in Würzburg, the central location and visibility of the protest resulted in a magnetic effect that attracted hundreds of individual supporters and groups as well as migrants from remote asylum facilities to join the protest. During the first months of the camp at Oranienplatz, the support from the local population was immense. Tens of thousands of euros were donated, but also food, clothes, and tents; local residents and owners of shops surrounding the camp offered their sanitary facilities for use. In most cases, it was enough to post an item on the "We Need" billboard at the entrance of the camp and it was organized shortly after. "When we arrived in Berlin [...] there was a lot of attention because 600 kilometers marching is something special. And when people [who wanted to support us] came, we said: it is good that you are here, and we need this and that" (Interview B4). Resources needed to sustain the protest could be mobilized on the spot, as the camp bundled multiple "weak ties" to civil society organizations, individual supporters and the media.

Immediately the Oranienplatz camp became a vibrant hub of political activity. Shortly after its establishment, the protesters called for a demonstration, to which around 6,0oo people attended. It was by the time one of the largest demonstrations led by precarious migrants in German history (Schreiter and Jakob 2012). Activist from the OPlatz joined forces with the Voice and occupied the Nigerian embassy in Berlin to draw attention to the African governments' role in deportations (Wendt 2012). Members of the Iranian core group, who had initiated the march in Würzburg, led a fourteen-day hunger strike at the Brandenburger Tor (Schreiter 2012), creating another protest arena with additional players, rules and audiences. The photos of hunger strikers in front of the famous landmark became iconic and attracted further attention to the protesters' demands. Warned by the incubating effects of inner-city hunger strikes in Würzburg, the conservative Senator for the Interior and Sport of Berlin, Frank Henkel (CDU), consequently tried to avoid the establishment of a protest camp in the political heart of the city and ordered harsh policing, including the confiscation of sleeping bags, sleeping pads and tents. This, in turn, generated further visibility of the protests, which culminated in a meeting of the striking migrant activists with members of the Committee on Human Rights and Humanitarian Aid and the Committee on Internal Affairs of the 
German parliament, the Bundestag (Spiegel Online 2012). In a very short period of time, the protesters had with their choice of sites and forms of protest both literally and metaphorically moved from the periphery to the very center of German politics. By this, the new generation of protesters achieved what previous self-organized migrant protests and the German promigrant movement had failed to do.

Simultaneously, in the midst of an icy Berlin winter, migrants and supporters from the second protest camp at Oranienplatz squatted an abandoned school building (the Gerhart-Hauptmann-Schule) within walking distance of the tent camp (Litschko 2012a). Imagined as a safe space for the winter, one floor of the building was transformed into an International Women's Space - a self-organized political space for migrant women (Interviews $\mathrm{B} 4, \mathrm{~B} 24)$.

Via online communication and word of mouth, many precarious migrants, both asylum seekers living in asylum facilities outside the urban centers and illegalized migrants, learned of the existence of the autonomous space and left their assigned location in asylum facilities (Interviews B4, B12). Dozens of precarious migrants had experienced the sheer existence of the OPlatz and its satellite (the occupied school) as a motivation to leave their designated asylum facilities in different parts of Germany to join the protests in Berlin or to engage in local refugee activism (Interviews B3, B12, B24). The camp was a docking station to meet other politically engaged people, to tap resources and to develop new ideas for political opposition. While many of the founders of the movement had previous experiences in political activism in their countries of origin, such as the Iranian core group in the Green Movement, the existence of the camp also attracted many for whom the camp was a space of politicization and socialization into activism. Indeed, the protesters actively encouraged asylum seekers from all over the country to join the protest: "We ask all of you, refugees and asylum seekers, around Germany to break the isolation and to break the silence and join your brothers and sisters at the protest camp at Oranienplatz to take what is your right" (Refugee Revolution 2013).

Hence, the camp, due to its magnetic effect on resources and activists, was not only a space of protest incubation, but also a space of encounter for an extremely heterogeneous group of precarious migrants and supporters with a plethora of legal status, social backgrounds, and ideologies. While "safe spaces" beyond the crippling control of the state have been considered key for all kinds of oppositional movements (Sewell 2001:69), asylum seekers and undocumented migrants are situated in an even more restrained system of control and precariousness, from which autonomous camps can provide 
(temporary) relief: "When we came here, it was reducing and healing the trauma. Because I got to know people here not by force. [...] In the Lagers [asylum facilities] [...] you have to be in this place whether you like or not. You are not allowed to move about. But here we can move freely. Nobody can say, 'Do not go there".?

This experience of autonomy and hope led various activists to (re)develop a sense of agency, which had gradually been replaced by apathy and despair during the asylum process. Asked by journalists why the protesters did not accept the deal offered by the local administration of Kreuzberg, to move back into asylum camps and get individual reviews of their asylum claims, an activist answered: "We are alone there; we cannot fight together. The authorities can take and deport us easily" (cited in International Refugee Center Berlin 2015: 77).

Assemblies were organized, translating interventions into multiple languages and, indeed, the process of developing and negotiating a collective identity did not evolve without frictions. Nevertheless, both camps created the very basis for developing "strong ties" among migrants and between migrants and supporters. The "eventful" character of the camp and the collective actions deepened a sense of collectivity despite diversity. Precarious migrants had, at least temporarily, resisted their social and spatial marginalization and articulated their political claims center stage: "They want to put us out of the city where nobody knows that we are existing. [...] Right here where we are is the right place" (International Refugee Center Berlin 2015: 8).

As this account underlines, precarious migrants had rapidly transformed themselves from "weakly resourced," isolated and dispersed individuals into an emerging movement with astonishing resources and means to organize and sustain the protest. The precarious migrants did not need to beg for scarce support but could even choose among various kinds of assistance offered by a multitude of actors. Due to this magnetic effect and the shift in power relations between migrants and supporters, at the beginning little energy was needed to sustain the protest activity.

\section{OPlatz as a Space of Protest Fragmentation}

As a result of the tremendous popularity, the supporters also partly changed, compared both to Würzburg and previous episodes of migrant activism. The dominant actors supporting the protesting migrants were individuals, referred to as "supporters," not the grassroots organizations forming 
the migrant rights movement at the time. For the protesting activists, the volatile and decentralized "support" base was convenient at the outset. Negotiations or compromises with established groups with explicit agendas were simply not necessary, and deliberately denied to guarantee autonomy: "We say it is self-organized because we ourselves will not connect to any big organizations. We don't want money from big organization. We get money from the population. We get support from the population" (Interview B4).

Grassroots organizations and NGOs active in the field of migrant support remained in the background or entirely absent. They either felt superfluous in light of the widespread individual support or had difficulties finding their role vis-à-vis the protesting migrant protagonists. Decisions were taken and information was shared with those present in the camp. This did not fit for those who had a representative role and only joined occasionally. Others were furthermore alienated by the spontaneous and action-oriented protest.

Sometimes, it was overwhelming to occupy an embassy, having a demo or being on a hunger strike every day. [...] In some moments, there was a lot of action and little coordination. I think those who conceived themselves to be more settled, both in terms of age and organizational experience, were overwhelmed by the spontaneity. (Interview B9)

What prevailed in the first phase of the protest was a dedicated group of supporters with an orthodox reading of "critical whiteness," which presupposed an articulately neutral role for the supporters. While decisions were taken by a migrant-only plenary, supporters sustained the infrastructure of the camp, engaged in care work, such as cooking, translation, organizing lawyers, and providing counseling and legal aid, organized PR activities such as press conferences and press releases (Langa 2015):

[Critical whiteness] has definitely led to a change of perspective, how racism is addressed, whose voice should be considered more important because of racism, and has pointed to the problems in the politics of representation. [...] My position, for instance, in the plenary, was to stay in the background. I really do not want to take up a lot of space, as a white guy with long experience in political activism. (Interview B25)

Nevertheless, this rigid distinction between the roles of "refugees" and "supporters" was also profoundly contested within the German antiracist left at the time (Karakayali et al. 2012; Jakob 2012). The conflicts had escalated at a "no border" camp in Cologne only a few months before the Oranienplatz 
camp started and left their marks: "German activists became messengers. This is how it developed. The refugees make decisions; the nonrefugee activist can build the tent, clean the tent, cook, collect money, but no discussion. [...] This stigma came out of the 'no border' camp [in Cologne]. It made them [German activists] feel: 'Do not speak'” (Interview B22).

Accordingly, many German supporters took a loyal and predominantly supporting role. The inner circle of regular encounter was also populated by members of the older generations of precarious migrant activism, such as the Caravan. Even though these interactions were crucial to access networks established in past mobilizations, the questions of representation and leadership that had emerged even before the march in Erfurt continued to be a constant source of conflict at Oranienplatz. This became particularly visible when the Iranian core group explicitly introduced the concept of "noncitizens," explaining: "Of course, we make a distinction between ourselves and recognized asylum seekers, even if they fight at our side. The recognized refugees can go home after the protest - we cannot. We do not have a home. On the contrary, we can be deported" (Jakob 2013, author's translation).

The result was a fundamental alienation of the Caravan activists, who considered this first and foremost as a strategy to silence opposition and secure their leadership in the emerging movement.

You cannot build trust like this, because you are suspicious. With these "noncitizens" who were the leadership you were taken to the point that you were automatically excluded when you had obtained papers. [...] The point was not so much the willingness to learn, it is more the question of how much they were influenced by their mindset of where they come from. [...] At the end the Caravan decided to pull out and let them do what they wanted. (Interview B11)

The debates had an impact on the trajectory of the protests early on. Indeed, the Iranian core group's decision to go on hunger strike at the Brandenburger Tor reflected these early dynamics of fragmentation. After the hunger strike, some of the protest protagonists did not even return to the Oranienplatz camp but split apart and opted for a continuation of their independent protest in Bavaria. While these internal divisions were present from the beginning, initially they could be compensated, given the incubating effect of a protest camp, attracting visibility, people, and resources.

In spring 2013, the situation changed gradually, but fundamentally, for various reasons. Firstly, a new compound player entered the arena: a growing 
number of mostly Sub-Saharan migrants, who had escaped the Libyan civil war via the Italian island of Lampedusa. Among those who eventually formed the Lampedusa group in Berlin were many who had temporary humanitarian protection status in Italy, without the right to work or social entitlements in Germany. Due to a lack of alternatives, many joined the squatted school and the occupied square, contributing to an increasing degradation of the places caused by overpopulation (Interviews B2, B15, B25). Many had never even filed an asylum claim in Germany and did not plan to do so. In consequence, the different legal status of precarious migrants in the square left their mark (Interviews B15, B21, B25) as it entailed fundamentally different political priorities.

The claims definitively changed. From the claims that were related to the situation of the "first generation," such as no camps, no deportation, no Residenzpflicht to those with Italian papers, who wanted access to the labor market - this was, in fact, their only claim. At the beginning they did align with the other claims and supported demonstrations as well, but it was obvious that they were not directly affected. Many did not even know what a refugee camp was, because they had never lived in one. [...] They also did not have experience of Residenzpflicht with their Italian papers. Hence, it was simply a totally different group. (Interview B21)

Whereas the initiators of the march and the camp had strong claims against the German asylum system and some had been politically active in their country of origin prior to arriving in Germany, the "new generation" faced a different legal situation, with an Italian humanitarian protection status, exhausted by long transmigration and time living on the streets in Italy and Germany. The "old generation" wanted to keep the square due to its incubating effect for protest. This "new generation" needed it as a space of subsistence and longed to put an end to their precarious life on the square: "Those who did not have any other place to stay were those with Italian papers and many of the first generation with more political demands [against the asylum system] already had shared flats, girlfriends or whatever and did come to the square for political fights and could leave in the evening to sleep in their warm beds" (Interview B21).

Hence, differences in status and levels of precariousness introduced divisions between the "generations" of precarious migrants occupying the square, with the tents of the Lampedusa group and the old generation starting to be deliberately separated within the camp (Doppler and Vorwergk 2014). The protest arena at Oranienplatz increasingly became a 
site in which internal actors competed for influence. These conflicts also involved the supporters of the early protest days with an articulate political and anticapitalist ideology:

I would say, those from the second generation wanted to become part of the system against which the supporters were fighting. [...] The people in the square, in fact, wanted to become part of the capitalist [world]. Of course, this does not apply to all of them, but many did, indeed, ask why the supporters thought the system was so terrible. They believed it was not so terrible - they just wanted to get into it. (Interview B21)

The combination of the camp as a space of subsistence and political activism in the same location had its downside. Initially, it mitigated the obstacle of mobilizing dispersed and financially precarious communities to participate in the protest and encouraged many to join. Yet, the longer the protest lasted, the more difficult and precarious the daily life in the tent camp became, gradually exhausting its inhabitants. This translated into fierce debates on how to spend the donations (for subsistence or political activity) in a moment when resources had stopped flowing in and the political context had shifted.

The same developments unfolded in the occupied school, a protest arena with its own specificities in terms of players, interests and rules. The place over time became predominantly a shelter, a place of subsistence rather than a space for political organization. The availability of shelter also attracted hundreds of individuals who were in need and only partially affiliated to the political struggle for rights and recognition. With an increasing population and unclear rules, conflicts multiplied. While this was also the case at OPlatz (Ünsal 2015), the material features of the occupied building posed specific challenges with regard to assuring the security and basic functioning of the place, including internal debates on access restrictions: "To squat the school was maybe our biggest mistake. We built our own Lager [camp]. We locked ourselves in again. With less visibility than in the public space and more controversies" (Interview B34).

The place became overcrowded and increasingly contested, receiving predominantly negative media coverage following outbursts of violence (Der Tagesspiegel 2013; rbb-online 2013; Soos 2014). These developments played into the hands of those who wanted to dismantle the disruptive sites of protest even long before, most prominently the conservative Senator of the Interior Henkel, who took the occasion to intensify his agitation against the protesters and the laissez-faire approach of the Green district government. 
In this phase the volatile and decentralized support base, which at the outset had contributed to the protest momentum, showed its downside. The lack of cultivated ties with established groups and organizations backfired, when the "hype" (Interviews B2, B4) around the camp faded and only a small and increasingly exhausted support base remained. In consequence, with the new generation of the Lampedusa group, a new generation of supporters emerged on the scene. Given the core interest of the group in eventually settling and improving their living conditions, some of the new supporters did not necessarily prioritize the political fight against the German asylum system. The multiple lines of internal divisions of both migrants and support groups, combined with the increasingly precarious conditions in both the school and the square, accentuated in the summer of 2013. Internal conflicts regarding sexism and homophobia (Refugee Strike Berlin 2013; Ünsal 2015) as well as conflicts involving neighbors (Kubsova 2013) were rapidly taken up by the media (Litschko 2013a; Biewald, Löbker, and Wehmeyer 2013). An inhabitant of the camp was stabbed by a Turkish migrant (Kopietz 2013). In this highly chaotic and contentious climate, a delegate for the Green Party in the district assembly decided to move into the tent camp to appease and moderate:

And then there was the day in June [...] when the knife attack happened. I lived in the neighborhood. [...] I felt the mood of the neighborhood. The Turks in the corner were upset. There was disappointment as well. This is often the case here in Kreuzberg. It is densely populated, and we live with very few resources that need to be shared. Particularly for the poorer parts of society, it was also a loss that half of the square was simply gone. [...] And in my role as local representative, I saw that more and more locals came by, saying, "It is too loud - we cannot work, we cannot sleep," etc., and they were just shouted at by the supporters, who said, "Why do you complain? These are refugees - they have real problems." So people got upset. (Interview B8)

While relations with the neighborhood improved subsequently, the delegate was fundamentally rejected by the older generation of migrant activists, and their surrounding supporters. They saw this intervention firstly as a return of paternalism with a white person representing the migrants and, secondly, as a clear move of co-optation by the district administration (Interviews B4, B25). "I definitely had the feeling that I was not welcome by some. Some people did not speak to me even once. It seems like some people did not like the idea at all that I moved into the camp. I did not even 
think about the possibility that someone might be against this. I thought they were happy!" (Interview B8).

Increasing mutual suspicion and a change in leadership of the Green Party in Kreuzberg finally introduced another major change. While the Green district administration had remained supportive of the camp for a long time (Litschko 2013b), and against the criticism of the Senator of the Interior of Berlin, the newly elected mayor of Kreuzberg, Monika Herrmann (still from the Greens), departed from her predecessor's laissez-faire strategy regarding the camp (Interview $\mathrm{B}_{7}$ ) and aimed at its dissolution, arguing:

My impression was that this was not really self-organized. [...] Yes, some of them from the Lampedusa group were also political, but the rest were not. They were first and foremost politically active with a view to leaving the camp and to getting a residence permit in Germany. But most of the protest originated from [...] supporters. A lot was projected onto these struggles. (Interview B7)

For Herrmann, a member of one of the more grassroots and left-wing factions of the Green Party, a violent eviction of the camp was no option. Instead, she insisted on a negotiated solution even though the Senate strongly advocated for an eviction by force. The protesters who had set up the camp and experienced its incubating role strongly opposed all attempts aiming at a dissolution of this space of contention: "[T] his is where they used other techniques. Someone came who knew everybody and said, "You are [in the] Lampedusa [group]. You are different - you can have more than the other people. [...] Until then they believed they were special. So we started fighting with each other" (Interview B4).

The strategy of selective incentives was effective, with the Lampedusa group in Berlin starting to show an interest in securing the housing solution for its members offered by the Senate. Whereas the first generation of migrant activists wanted to keep the camp as a space of political protest for the rights of asylum seekers in Germany (Interviews B2, B4; Loy, Buntrock, and Dassler 2013). In autumn and winter 2013, lengthy negotiations unfolded between the protesters, the Senate and various observing associations, culminating in the so-called Oranienplatz Agreement signed in April 2014 by some factions of the protesters (Amjahid 2014). The agreement included a list of reportedly 462 (Amjahid 2014) individuals in the school and in the square, who agreed to dismantle the protest camp themselves in exchange for an individual (re)assessment of their legal status (Senate of Berlin 2014). 
Some of the protesting migrants and supporters, however, fiercely opposed the agreement.

On the day of dissolution, a bizarre scene unfolded (Staiger 2014): migrants were tearing down tents and huts, at times shouted at by other protesters of the first generation and supporters. The supporters on the scene found themselves in the confusing situation where they were not mainly confronting the police, as expected, but instead were facing some of the very individuals they had been protesting with previously. While episodes of violence erupted between the two groups, the heavy police presence remained mainly in the background. A migrant rights activist recalled, disillusioned: "Toward the end of Oranienplatz, the movement was easy to attack, because it was easy to divide - this is what the Senator used in the end. Inviting only some factions of the camp, offering incentives and selling it as a solution for the entire Oranienplatz" (Interview B19).

Within the first generation and some of the supporters, the expression "divide and rule" (Interviews B4, B24, B25) became the standard description of the final phase of the camp. Herrmann and the Greens lost their credibility and from being an ally turned into one of their key opponents (Flüchtlingsrat Berlin 2014).

The dissolution of the camp wiped out the material and symbolic center of the protest arena. In its absence, the spatial importance of the camp for the movement became even more evident. Difficulties for refugees to meet and organize grew substantially:

Now that there is no Oranienplatz anymore it is difficult to meet. We all live in different places now. I live far away, far, far away, I tell you! By bus and train it takes maybe one hour before I get to the [occupied] school. I can't go by bicycle. I would get lost as I don't know the road! Now maybe it can be one month or two months that we do not meet each other, because now we are separate. But before, when we were living in Oranienplatz, you went there and there were many of us, every time! We could sit together, talk. (Quoted in Borri 2016)

Two months after the dismantling of the protest camp at Oranienplatz, the district intended to proceed similarly with the occupied school. Due to the symbolic value the school had obtained after the end of the OPlatz camp, as well as the resistance of some of its inhabitants on the roof, thousands of political activists and neighbors prevented an eviction of the place in summer 2014 (Danielzik and Bendix 2016). Despite this highly mediatized dissent of around two dozen activists, the majority accepted the offer, 
including most of the women who had been settled in the International Women's Space. Particularly for the Women's Space, which was, in the end, one of the few groups with an explicit activist focus in the school, the loss of this site was a hard blow.

It was a very difficult moment. After the eviction, everyone was displaced, virtually everybody. [...] Now we changed situations from having a place to work and sleep to not even having a place to meet, just something very basic. So, we started looking around for women's organizations, which already have establishments, [...] but we still did not enjoy the sense of freedom, the sense of everything, that we enjoyed in the school. (Interview B24)

The alternative accommodation which was offered in exchange for leaving the autonomous protest spaces were provided for six months. As it turned out, by the time the former occupants of the OPlatz camp were sent out of the reception centers and became homeless, the supporters network had also been notably weakened. Many had abandoned the movement because they did not want the Oranienplatz Agreement. Those few who remained now struggled to secure their basic needs and support the ongoing precarious protests, which had by now fragmented into many protests across the city. Public interest in the migrants and their claims had in the meanwhile diminished. The eradication of the main spaces of contention resulting in the dispersal of precarious migrants had effectively fragmented the protest.

Migrant protest continued throughout the summer and autumn of 2014 at various locations in and around Berlin. They intensified particularly when those evacuated from the camp and school were ordered to leave the temporary shelters and return to their allocated district, where their asylum claim had been registered, or to go back to Italy for those with humanitarian protection status (Kögel et al. 2014; Berliner Zeitung 2014). In early 2015, the protests faded out, even though some of the migrant activists involved remain engaged in various antiracist groups until today.

\section{Conclusion}

The Oranienplatz protests unveiled that precarious migrants were able to raise public attention and mobilize asylum seekers and the media by moving from socially and spatially isolated locations into urban centers. In organizing central protest camps, marches and bus tours, they literally 
left behind their excluded position and articulated a claim to urban and social centrality. The relocation from the periphery of their designated asylum facilities to the inner-city space furthermore broke the routine of precarious migrant invisibility or victimization through extensive media coverage, and by this tapped the resources needed to sustain political mobilizations. The camps generated "magnetic fields," attracting diverse support milieus from which asylum seekers had been previously cut off. The protesters gradually succeeded in compensating the lack of resources and even in altering established power relations between migrants and pro-beneficiaries. The latter were attracted to the prominent protesters, who had, hence, a degree of choice in deciding with whom to work and whom to ignore. In addition to constituting reservoirs for weak ties, the protest camps also served as spaces of encounter and trust building among a previously scattered precarious migrant community. Stories and opinions could be shared and a collective identity was developed, despite the tremendous heterogeneity of the actors involved. In consequence, individuals from a wide range of social and geographical backgrounds joined the movement and organized for an extensive period of time dozens of protest events and constituted themselves as political subjects in the public sphere. This account clearly shows that the protesters did not react upon opening opportunity structures, as the traditional social movement theories would expect. Rather, their protest, emerging in the most restrictive regional context for asylum seekers in Bavaria, actively opened opportunities that were subsequently incubated in the German capital.

Nevertheless, the trajectory of the OPlatz protests also unveil the contentious nature of interactions in precarious activism. It points to the difficulties of uniting a highly heterogeneous compound actor, with distinct legal statuses and hence the eligibility for services, and the likelihood of detention and deportation. Such practices influence not only the status of the individuals in question but also their relationships within the migrant community, civil-society organizations and the state. Macroinstitutions such as legal systems (and hence, potential legal statuses) intervene in the making and breaking of social ties - not least in collective action - as they provide multiple incentives to defect from collective political campaigning and opt for individual niche openings. Such individual solutions are particularly appealing when individuals find themselves in extremely precarious conditions for an extensive period of time. Precarious migrant activism is, therefore, characterized by multiple fault lines, which can be temporarily overcome under certain conditions, yet, remain a permanent Achilles' heel for sustained contention. 


\section{References}

Amjahid, Mohamed. 2014. "Die geheimen Verhandlungen zwischen Senat und den Flüchtlingen." Der Tagesspiegel, 27 September. http://www.tagesspiegel.de/ berlin/bezirke/friedrichshain-kreuzberg/fluechtlingsprotest-am-oranienplatzin-berlin-die-geheimen-verhandlungen-zwischen-senat-und-den-fluechtlingen/10762246.html.

ARD Tagesschau. 2012. "Tagesschau vom 5.10.2012." ARD Tagesschau. http://www. tagesschau.de/multimedia/sendung/ts37274.html.

Augsburger Allgemeine. 2012. "Münder zugenäht: Verzweifelte Iraner verschärfen ihren Streik." Augsburger Allgemeine, 4 June. http://www.augsburger-allgemeine. de/bayern/Muender-zugenaeht-Verzweifelte-Iraner-verschaerfen-ihren-Streikid20442026.html.

Berliner Zeitung. 2014. "Flüchtlinge jetzt in sechs Ersatzquartieren." Berliner Zeitung, ${ }_{15}$ September. http://www.tagesspiegel.de/berlin/bezirke/friedrichshain-kreuzberg/berlin-kreuzberg-fluechtlinge-jetzt-in-sechs-ersatzquartieren/10698518.html.

Biewald, Nicole, Jörg Löbker, and Jan C. Wehmeyer. 2013. "Senat will Kreuzberg zur Räumung zwingen.” Die Bild, 24 July. http://www.bild.de/regional/berlin/ fluechtling/senat-will-kreuzberg-zur-raeumung-zwingen-31525816.bild.html.

Borri, Giulia. 2016. “'Stuck in Movement': Refugees' Experiences of Protracted Precariousness across Turin and Berlin.” Humboldt University Berlin.

Danielzik, Chandra-Milena, and Daniel Bendix. 2016. "Neighbours Welcome! - Die Willkommenskultur, die Geflüchteten-Bewegung und die Suche nach Gemeinsamkeiten der Kämpfe um Rechte." In Grenzregime III: Der Lange Sommer Der Migration, edited by Sabine Hess, Stefanie Kron, Bernd Kasparek, Mathias Rodatz, Maria Schwert, and Simon Sontowski, 196-206. Berlin: Assoziation A.

della Porta, Donatella. 2008. "Eventful Protest, Global Conflicts.” Distinktion: Scandinavian Journal of Social Theory 9 (2): 27-56.

Der Tagesspiegel. 2013. "SEK stürmt besetzte Schule in Kreuzberg." Der Tagesspiegel, 14 November. http://www.tagesspiegel.de/berlin/polizei-justiz/messerstechereiunter-fluechtlingen-sek-stuermt-besetzte-schule-in-kreuzberg/9073688.html.

Die Welt. 2012. "Iraner nähen sich aus Protest den Mund zu." Die Welt, 6 June. https://www.welt.de/politik/deutschland/article106423984/Iraner-naehensich-aus-Protest-den-Mund-zu.html.

Doppler, Lisa, and Friederike Vorwergk. 2014. "Zwischen Identität und Solidarität." Hinterland Magazin, no. 24: 25-28. http://www.hinterland-magazin.de/wpcontent/uploads/2016/11/hinterland-magazin-24-25-zwischen-identitaet-undsolidaritaet-pdf.pdf.

Flüchtlingsrat Berlin. 2014. "Stellungnahme des Flüchtlingsrats Berlin zur Räumung des Oranienplatzes und die Verhandlung durch Frau Kolat.” Oplatz.net, 16 April. 
https://oplatz.net/stellungnahme-des-fluchtlingsrats-berlin-zur-raumung-desoranienplatzes-und-die-verhandlung-durch-frau-kolat/.

Grünberg, Matthias. 2013. Iraner im Hungerstreik Würzburg. Phase I. 19.03.2012 bis 04.o6.2012. Berlin: epubli GmbH.

Guyton, Patrick. 2012. "Protestmarsch nach Berlin." Badische Zeitung, 20 September. https://www.badische-zeitung.de/deutschland-1/protestmarsch-nachberlin--63887834.html.

Hosinazadeh, Masoud, and Shahanaz Maorattab. 2012. "Pressemitteilung seitens iranischer Asylbewerber der Stadt Würzburg (Bayern, Deutschland).” Würzburg: Indymedia. https://linksunten.indymedia.org/de/node/56767.

International Refugee Center Berlin, ed. 2015. Movement Magazine.

Jakob, Christian. 2012. "Weiß sein, Schnauze halten." Jungle World, 26 July. https:// jungle.world/artikel/2012/30/weiss-sein-schnauze-halten.

—. 2013. "Aufstand der Nichtbürger." Jungle World, 28 February. http://jungle-world. com/artikel/2013/og/47223.html.

—. 2016. Die Bleibenden. Wie Flüchtlinge Deutschland seit 20 Jahren verändern. Berlin: Ch. Links Verlag.

Jungbauer, Andreas. 2012. "Selbstmord in Asylheim: Trauer um Flüchtling." Main Post, 30 January. http://www.mainpost.de/regional/wuerzburg/ Altaere-Asylheime-Fluechtlinge-Selbstmord-Teig-Trauer;art735,6588549.

Karakayali, Jule, Vassilis Tsianos, Serhat Karakayali, and Aida Ibrahim. 2012. “Decolorise It! Die Rezeption von Critical Whiteness hat eine Richtung eingeschlagen, die die antirassistisch Politiken sabotiert." Ak-Analyse \& KritikAnalyse \& Kritik, no. 575. http://www.akweb.de/ak_s/ak575/23.htm.

Kögel, Annette, Milena Menzemer, Tassilo Hummel, and Bodo Straub. 2014. "Flüchtling droht mit Sprung vom Hostel-Dach." Der Tagesspiegel, 27 August. http://www.tagesspiegel.de/berlin/berlin-friedrichshain-fluechtling-droht-mitsprung-vom-hostel-dach/10608224.html.

Kopietz, Andreas. 2013. "Messerstich im Flüchtlingscamp." Berliner Zeitung, 18 June. http://www.berliner-zeitung.de/berlin/polizei/protestcamp-messerstich-imfluechtlingscamp-4422868.

Kubsova, Jarka. 2013. “Gekommen, um zu bleiben.” Der Stern, 6 August. https:// www.stern.de/politik/deutschland/asylanten-in-deutschland-gekommen--umzu-bleiben-3371352.html.

Landesflüchtlingsräte and Pro Asyl. 2012. "Gemeinsame Pressemitteilung der Landesflüchtlingsräte und PRO ASY o6.o9.12: Flüchtlingsprotestmarsch von Würzburg nach Berlin.” http://www.fluechtlingsrat-berlin.de/print_pe2. php?post_id=611.

Langa, Napuli. 2015. "About the Refugee Movement in Kreuzberg/Berlin." Movements $1(2): 1-10$. 
Lindner, Eva. 2012. "Marsch nach Berlin soll Lage von Asylsuchenden verbessern.” Berliner Morgenpost, 6 October. http://www.morgenpost.de/berlin/article1og663173/Marsch-nach-Berlin-soll-Lage-von-Asylsuchenden-verbessern.html.

Litschko, Konrad. 2012a. "Flucht vor dem Schnee." Die Tageszeitung, 9 December. https://taz.de/Protest-in-naechster-Runde/!5077622/.

—. 2012b. "Wieder im Hungerstreik." Die Tageszeitung, 16 November. https://taz. de/Fluechtlingsprotest-in-Berlin/!5079274/.

—. 2013a. "Im Schlepptau des Boulevards." Die Tageszeitung, 26 July. https://taz. de/Falschmeldung-ueber-Refugeecamp/!5062386/.

—. 2013b. "Kreuzberg duldet keine Flüchtlinge." Die Tageszeitung, 24 November. https://taz.de/Asylsuchende-auf-dem-Oranienplatz/!5054229/.

Loschert, Sebastian. 2012. "Marsch ohne Manager." Jungle World, 11 October. https:// jungle.world/artikel/2012/41/marsch-ohne-manager.

Loy, Thomas, Tanja Buntrock, and Sandra Dassler. 2013. "Ultimatum für den Oranienplatz." Der Tagesspiegel, 27 November. https://www.tagesspiegel.de/ berlin/ultimatum-fuer-den-oranienplatz/9132296.html.

Main Post. 2012a. "Hungerstreik: Haderthauer bleibt hart." Main Post, 3 April. https:/ www.mainpost.de/regional/franken/Fluechtlinge-Hungerstreiks-Migration-Re chtsstaatlichkeit;art1727,6712885.

—. 2012b. "Wer mag schon Radikale?" Main Post, 4 June. http://www.mainpost. de/regional/franken/Fluechtlinge;art1727,6824972.

Markus, Barbara. 2012. "Gegen Residenzpflicht, Gemeinschaftsunterkünfte und Abschiebung." Deutschlandfunk, 6 September. https://www.deutschlandfunk.de/gegen-residenzpflicht-gemeinschaftsunterkuenfte-und.862. de.html?dram:article_id=219140.

Möller, Kornelia. 2012. "Verschärfter Hungerstreik der iranischen Flüchtlingen mit zugenähten Mündern.” 13 June. http://www.die-linke-bayern.de/parlamente/ in_den_bezirkstagen/details/zurueck/in-den-bezirkstagen/artikel/verschaerfterhungerstreik-der-iranischen-fluechtlingen-mit-zugenaehten-muendern/.

Neuert, Lisa. 2012. "Wer mag schon Ungerechtigkeit?" Main Post, 11 June. https:// www.mainpost.de/ueberregional/meinung/leserbriefe/Wer-mag-schon-Unge rechtigkeit;art17031,6836023.

Pro Asyl. 2012. "Flüchtlingsprotestmarsch von Würzburg nach Berlin." https://www.proasyl.de/pressemitteilung/fluechtlingsprotestmarsch-von-wuerzburg-nach-berlin/.

Pro Asyl and Flüchtlingsrat Berlin e.V. 2012. "Gemeinsame Presseinformation von PRO ASYL und Flüchtlingsrat Berlin 31.10.12: Hungerstreik am Brandenburger Tor/Protest Ermöglichen - Versammlungsfreiheit Achten."

Przybilla, Olaf. 2012a. "Asylbewerber nähen sich die Lippen zu." Süddeutsche Zeitung, 4 June. http://www.sueddeutsche.de/bayern/spektakulaerer-protestin-wuerzburg-asylbewerber-naehen-sich-die-lippen-zu-1.1374149. 
—. 2012b. “Iraner brechen Hungerstreik ab.” Süddeutsche Zeitung, 4 April. http:// www.sueddeutsche.de/bayern/neue-hoffnung-fuer-asylbewerber-in-wuerzburgiraner-brechen-hungerstreik-ab-1.1326493.

—. 2012c. "Lauter Streit über zugenähte Lippen." Süddeutsche Zeitung, 30 June. http://www.sueddeutsche.de/bayern/protestaktion-in-wuerzburg-lauter-streitueber-zugenaehte-lippen-1.1388681.

rbb-online. 2013. "Kritik an SEK-Einsatz in Besetzter Schule." http://www. rbb-online.de/politik/beitrag/rc/gerhart-hauptmann-schule-sek-einsatzfluechtlinge.html.

Refugee Revolution. 2013. "Bustour." http://refugeesrevolution.blogsport.de/bustour/. Refugee Strike Berlin. 2013. "Fight Racism/Fight Sexism! Pressekonferenz am 29.7. auf dem Oranienplatz." Oplatz.net, 30 July. https://asylstrikeberlin.wordpress. com/2013/07/30/fight-racism-fight-sexism-press-conference-29-01-2013/.

Refugee Tent Action. 2012. "Geschichte des Protests/Selbstdarstellung der protestierenden Flüchtlinge." September. http://karawane-muenchen.org/files/2012/og/ Geschichte-Flüchtlingsprotest-zur-Dokumentation.pdf.

Rogalla, Thomas. 2012. "Dann müssen wir ihnen eben die Türen öffnen." Berliner Zeitung, 5 November. https://www.berliner-zeitung.de/berlin/fluechtlingsproteste--dann-muessen-wir-ihnen-eben-die-tueren-oeffnen--5816768.

Schreiter, Nikolai. 2012. "Sie beißen die Zähne zusammen.” Die Tageszeitung. 24 October. https://taz.de/Protest/!5081028/.

Schreiter, Nikolai, and Christian Jakob. 2012. "Das war Berlin, jetzt kommt Europa.” Die Tageszeitung. Berlin. http://www.taz.de/!5081849/.

Senate of Berlin. 2014. "Einigungspapier Oranienplatz." https://www.berlin.de/ rbmskzl/_assets/aktuelles/2014/maerz/einigungspapier_oranienplatz.pdf.

Sewell, William. 2001. "Space in Contentious Politics." In Silence and Voice in the Study of Contentious Politics, edited by Ronald Aminzade, Jack Goldstone, Doug McAdam, Elizabeth Perry, William Sewell, Sidney Tarrow, and Charles Tilly, 51-88. Cambridge: Cambridge University Press.

Soos, Oliver. 2014. "Anarchie in besetzter Schule?" RBB 24, 3 February, https://www. rbb24.de/politik/thema/fluechtlinge/berlin/alte-beitraege/reportage-besetzteschule-kreuzberg.html.

Spiegel Online. 2012. "Flüchtlinge beenden Hungerstreik." Spiegel Online, 2 November. http://www.spiegel.de/politik/deutschland/fluechtlinge-beendenhungerstreik-am-brandenburger-tor-a-864931.html.

Staiger, Marcus. 2014. "Hämmer, Brecheisen und Messer - Die Räumung des Berliner Refugee-Camps." Vice, April. https://www.vice.com/de/article/8gbaeg/ berlin-oranienplatz-refugee-camp-raeumung.

Ullrich, Peter. 2013. Deutsche, Linke und der Nahostkonflikt:Politik im Antisemitismusund Erinnerungsdiskurs. Göttingen: Wallstein. 
Ünsal, Nadiye. 2015. “Challenging 'Refugees' and 'Supporters': Intersectional Power Structures in the Refugee Movement in Berlin." Movements 1 (2): 1-18.

The Voice. 2012. "The VOICE Refugee Forum: Aufruf für Unterstützung und spenden zum Break Isolation! Refugee Summer Camp in Erfurt, Thüringen." http:// breakisolation.blogsport.de/2012/08/07/the-voice-refugee-forum-aufruf-fuerunterstuetzung-und-spenden-zum-break-isolation-refugee-summer-camp-inerfurt-thueringen/\#more-34.

Wendel, Kay. 2014. Unterbringung von Flüchtlingen in Deutschland: Regelungen und Praxis der Bundesländer im Vergleich, August. Frankfurt: Pro Asyl. https:// www.proasyl.de/wp-content/uploads/2014/og/Laendervergleich_Unterbringung_2014-09-23_02.pdf.

Wendt, Johannes. 2012. "Flüchtlinge besetzen Botschaft." Die Tageszeitung, 15 October. https://taz.de/Protest-gegen-Anhoerungen/!5081767/. 